\title{
Economic Evaluation of Hydraulic Fracturing in a Gas Condensate Reservoir Operating below Dewpoint
}

\author{
Anthony Kerunwa, Princewill 0. Ariche, Nkemakolam Chinedu Izuwa \\ Federal University of Technology, Owerri, Nigeria \\ Email: anthonykerunwa@rocketmail.com, aricheprincewill@gmail.com,n.c.izuwa@gmail.com
}

How to cite this paper: Kerunwa, A., Ariche, P.O. and Izuwa, N.C. (2020) Economic Evaluation of Hydraulic Fracturing in a Gas Condensate Reservoir Operating below Dewpoint. Open Journal of Yangtze Gas and Oil, 5, 73-86.

https://doi.org/10.4236/ojogas.2020.53007

Received: April 6, 2020

Accepted: May 11, 2020

Published: May 14, 2020

Copyright $\odot 2020$ by author(s) and Scientific Research Publishing Inc. This work is licensed under the Creative Commons Attribution International License (CC BY 4.0).

http://creativecommons.org/licenses/by/4.0/

\begin{abstract}
Hydraulic fracturing is among the approaches used to optimize production from a gas condensate reservoir. A detailed economic analysis is required to evaluate the profitability and feasibility of hydraulic fracturing as an optimization option in a gas condensate reservoir operating below dewpoint. The objective of this research is to evaluate the economic benefits derivable from the use of hydraulic fracturing to improve gas and liquid recovery from a gas condensate reservoir operating below dewpoint. This research considers the use of four profit indicators to ascertain the profitability of hydraulic fracturing in a gas condensate reservoir operating below dewpoint by increasing the fracture halflength, fracture width and fracture permeability. The production data of the reservoir was obtained and the economic calculations done on excel spreadsheet and plots generated. The four profit indicators considered in the research are Net Present Value, Payout, Discounted Cash Flow Rate of Return and Profit per Dollar Invested. The economic justification was done by carrying out a comparative economic analysis from the result obtained when the reservoir of study was unfractured with that obtained when the reservoir was fractured at various fracture parameters. The economic analysis was done considering a royalty and tax rate of $18.5 \%$ and $30 \%$ respectively and a gas price of $\$ 2 / \mathrm{MSCF}$ and condensate price of $\$ 30 / \mathrm{bbl}$. This is done so as to find out if the additional cost of hydraulic fracturing can be offset by the recovery from the reservoir when its pressure declined below dewpoint. The result obtained showed that the additional recovery due to hydraulic fracturing by increasing the fracture halflength, fracture width and fracture permeability was not enough to justify the application of hydraulic fracturing when the reservoir pressure declined below dewpoint.
\end{abstract}

\section{Keywords}

Economic Evaluation, Fracture Halflength, Proppants, Profit Indicators, 
Hydraulic Fracturing, Gas Condensate Reservoir, Dewpoint

\section{Introduction}

Gas condensate reservoir is among the types of reservoirs that we have and as such it represents a major source of hydrocarbon. Gas condensate reservoir is a reservoir that contains a thermodynamically special kind of reservoir fluid; its reservoir temperature is above the critical temperature $\left(\mathrm{T}_{\mathrm{C}}\right)$ but less than the cricondentherm $\left(\mathrm{T}_{\mathrm{Ct}}\right)$ on the pressure-temperature diagram [1]. Gas condensate reservoir is of economic importance as a result of the additional liquid produced when the reservoir pressure drops below dewpoint. At pressures below dewpoint pressure of the reservoir, liquid drops out of the gas phase in a process known as condensate banking. This dropped out liquid plugs the pore spaces thereby limiting the flow of gas through the porous medium. One of the methods used to improve recovery from a gas condensate reservoir is hydraulic fracturing. A well's ability to produce hydrocarbons or receive fluids that are injected is limited by the natural permeability of the reservoir and then changes in near-wellbore that results from drilling and/or other operations. Hydraulic fracturing, otherwise called hydraulic stimulation, causes an improvement in the flow of hydrocarbon by the creation of fractures in the formation connecting the wellbore and reservoir. A hydraulic fracture involves inducement of fracture through pressure by the injection of fluid into a target reservoir rock formation. Fluid is then pumped into the rock formation at high pressures that are far above the fracture pressure-the rocks breaking pressure [2]. Hydraulic Fracturing involves the injection of a large volume of frac fluids into the well under high pressure to fracture the reservoir rock. It involves pumping fluid into a wellbore faster than the escape of the fluid into the formation causing enormous rise in pressure, thereby leading to the creation of cracks in the deep formation-rocks through which brine, natural gas and crude oil will easily flow through [3]. The fracturing fluid used is primarily water that contains sand or some other proppants that are suspended with the help of a thickening agent. Hydraulic fracturing is mostly suited to wells in low and moderately permeability reservoirs that do not provide commercial production rates [4]. Hydraulic fracturing performs the primary objective of increasing the well contact area by increasing the wellbore radius and enhancing the productivity of the well by achieving linear flow instead of radial flow when fluid is going inside the wellbore [5]. However, hydraulic fracturing does not eliminate condensate accumulation in areas where the pressure in the formation is below dewpoint. It only delays the time of reaching the dew point pressure but does not completely prevent condensate blockage [6]. In this work, Economic Analysis of hydraulic fracturing was carried out to ascertain if hydraulic fracturing will be a better alternative to optimize liquid and gas recovery from a gas condensate reservoir operating below dewpoint due to liquid blockage effect. Various profit indicators 
such as Net Present Value, Discounted Cash Flow Rate of Return, Payout Time and Profit per Dollar Invested were considered to ascertain the profitability of Hydraulic Fracturing technique in improving recovery from gas condensate reservoir operating below dewpoint.

\section{Literature Review}

From the vast literature survey, it is clear that in the past many researchers have done a lot of research on gas condensate reservoir and the various ways to optimize production from this type of reservoir. A brief insight to some of the literature reviewed during the research is outlined below:

Andrey et al., (2016) [7] carried out a research on economic analysis and optimization of fracture-stimulated wells in condensate reservoirs. In their study, they built and validated a numerical model for production decline calculation in condensate reservoir with transient analysis of three phase pressure distribution. The model developed has been used for the sensitivity analysis study of reservoir productivity involving spacing and fracture size changes and the permeability of condensate reservoirs which was fractured, thereby accounting for the properties of the reservoir as well as multiphase flows of such reservoir. Ignatyev et al., (2011) [8] evaluated horizontal wells' hydraulic fracturing as an approach for effectively developing gas/condensate Arctic region fields. They established that horizontal wells' productivity with fractures was much greater than horizontal well's production without fractures nine times and thrice bigger than fractured vertical wells. They posited that in horizontal wells multistage type of fracturing lowered the losses occurring in condensate together with the drawdown then lifted up the PI of the well. Zeeshan et al., (2016) [5] utilized a novel approach to optimize the parameters of hydraulic fracturing in gas condensate reservoirs. They highlighted the effect of skin damage due fracture face associated with the length and width of hydraulic fractures and suggested that while designing fracture operations for gas condensate reservoirs, one should keep the fracture half-length, fracture width and fracture permeability high while fracture face skin should be small around the vicinity of the wellbore. Sheraz et al., (2016) [9] carried out a research on recovery enhancement in a gas condensate reservoir with low permeability through the technologies of hydraulic fracturing and EOR. They investigated the impact of coupling and inertia on hydraulically fractured wells, using $3 \mathrm{D}$ reservoir simulation on real time data. They presented a comprehensive strategy that detailed all the factors having maximum influence on ultimate recovery and verified the operational and economic aspects of such technologies, to increase the overall gas and condensate production from the field. Ravari et al., (2005) [10] conducted a research on gas condensate damage that occurred in hydraulically fractured wells. In their study, they used compositional reservoir simulation to model production for three scenarios; all having low permeability with hydraulic fractures. The simulation results showed that lower wellbore pressures yielded higher production rates which were in agreement with field results. Even though they observed damage to condensate well 
below the dewpoint, there was no case that showed reduced pressure at borehole led to extremely poor well performance. Even for the case of very rich gas condensate, the optimum conditions correspond to the lowest Pwf. Mogan et al., (2006) [11] carried out a research on non-darcy flow effect on the productivity of a gas condensate well that was hydraulically fractured. They utilized two level local grid refinements to show that very small grid blocks corresponding to actual fracture width could be simulated. An actual fracture width was used to accurately model non-darcy flow. The results of the simulation show that there was overestimation of productivity improvements by a high factor of three if non-darcy flow is neglected. Factors different from the ones mentioned earlier that control the improvement of productivity like well flow rates, fracture conductivity, fracture length as well as the parameters of reservoir were also studied.

\section{Methodology}

In the bid to present a detailed economic evaluation of hydraulic fracturing in gas condensate reservoir operating below dewpoint, the research adopts three approaches:

1) Obtaining hydraulic fracturing parameter of the gas condensate reservoir under study

2) Obtaining the production and input data of the gas condensate reservoir of study.

3) Using profit indicators to carry out economic calculations to ascertain the profitability of the hydraulic fracturing technique.

\subsection{Hydraulic Fracturing Parameter}

Hydraulic fracturing was used as a well stimulation approach in order to optimize production from the reservoir of study when the reservoir pressure dropped below dewpoint as a result of liquid dropout. The hydraulic fracturing job was done at various fracture parameters. The fracture parameters considered are fracture halflength (Xf), fracture width (Wf) and fracture permeability (Kf). During the hydraulic fracturing job three cases were considered. These are:

CASE 1: $\mathrm{X}_{\mathrm{f}}=1000 \mathrm{ft}, \mathrm{W}_{\mathrm{f}}=0.03 \mathrm{ft}, \mathrm{K}_{\mathrm{f}}=1000 \mathrm{md}$.

CASE 2: $\mathrm{X}_{\mathrm{f}}=2000 \mathrm{ft}, \mathrm{W}_{\mathrm{f}}=0.06 \mathrm{ft}, \mathrm{K}_{\mathrm{f}}=2000 \mathrm{md}$.

CASE 3: $\mathrm{X}_{\mathrm{f}}=3000 \mathrm{ft}, \mathrm{W}_{\mathrm{f}}=0.1 \mathrm{ft}, \mathrm{K}_{\mathrm{f}}=3000 \mathrm{md}$.

\subsection{Production and Input Data}

The gas and liquid production data was obtained from the reservoir when it is unfractured and when it is fractured at various fracture halflength, fracture width and fracture permeability. This is done so as to evaluate the economic viability of the hydraulic fracturing job. In both cases no form of pressure maintenance was done to the reservoir. Production of the reservoir fluid was done using the reservoir energy. The production data were collected for a period of ten (10) years. The reservoir fluid was produced at a rate of 40,000 MSCF/D. Other input data such as investment cost, operating cost, royalties and taxes 
payable for these projects were obtained and used in the analysis. The production data are shown in Table 1 and Table 2 below while the CAPEX for the different cases considered are shown in Table 3.

Table 1. The Cumulative Liquid Production for the different cases considered.

\begin{tabular}{|c|c|c|c|c|}
\hline YEAR & $\begin{array}{c}\text { FLPT (STB) FOR } \\
\text { UNFRACTURED CASE }\end{array}$ & $\begin{array}{c}\text { FLPT }(\mathrm{STB}) \text { FOR XF }=1000 \mathrm{FT}, \\
\mathrm{WF}=0.03 \mathrm{FT}, \mathrm{KF}=1000 \mathrm{MD}\end{array}$ & $\begin{array}{c}\text { FLPT }(\mathrm{STB}) \mathrm{FOR} X \mathrm{XF}=2000 \mathrm{FT}, \\
\mathrm{WF}=0.06 \mathrm{FT}, \mathrm{KF}=2000 \mathrm{FT}\end{array}$ & $\begin{array}{c}\text { FLPT (STB) FOR XF }=3000 \mathrm{FT}, \\
\mathrm{WF}=0.1 \mathrm{FT}, \mathrm{KF}=3000 \mathrm{MD}\end{array}$ \\
\hline 1 & $253,192.86$ & $253,192.86$ & $253,192.86$ & $253,192.86$ \\
\hline 2 & $484,541.72$ & $490,540.25$ & $490,551.19$ & $490,640.75$ \\
\hline 3 & $666,909.06$ & $684,208.69$ & $684,240.88$ & $684,458.75$ \\
\hline 4 & $800,764.13$ & $833,562.5$ & $833,623.75$ & $833,988.5$ \\
\hline 5 & $889,688.25$ & $940,845.69$ & $940,941.31$ & $941,466.5$ \\
\hline 6 & $939,643.56$ & $1,010,093.9$ & $1,010,226.7$ & $1,010,919.3$ \\
\hline 7 & $957,482.44$ & $1,046,489.3$ & $1,046,659.1$ & $1,047,517.9$ \\
\hline 8 & $957,802.75$ & $1,055,935.5$ & $1,056,136.6$ & $1,057,138.6$ \\
\hline 9 & $957,802.75$ & $1,055,935.5$ & $1,056,136.6$ & $1,057,138.6$ \\
\hline 10 & $957,802.75$ & $1,055,935.5$ & $1,056,136.6$ & $1,057,138.6$ \\
\hline
\end{tabular}

Table 2. The Cumulative Gas Production (FGPT) for the different cases considered.

\begin{tabular}{|c|c|c|c|c|}
\hline \multirow{2}{*}{ YEAR } & FGPT(MSCF) FOR & FGPT (MSCF) FOR XF = 1000 & FGPT (MSCF) FOR XF $=2000$ & FGPT (MSCF) FOR XF = 3000 \\
\hline & UNFRACTURED CASE & $\mathrm{FT}, \mathrm{WF}=0.03 \mathrm{FT}, \mathrm{KF}=1000 \mathrm{MD}$ & $\mathrm{FT}, \mathrm{WF}=0.06 \mathrm{FT}, \mathrm{KF}=2000 \mathrm{FT}$ & $\mathrm{FT}, \mathrm{WF}=0.1 \mathrm{FT}, \mathrm{KF}=3000 \mathrm{MD}$ \\
\hline 1 & $14,400,000$ & $14,400,000$ & $14,400,000$ & $14,400,000$ \\
\hline 2 & $28,800,000$ & $28,800,000$ & $28,800,000$ & $28,800,000$ \\
\hline 3 & $43,200,000$ & $43,200,000$ & $43,200,000$ & $43,200,000$ \\
\hline 4 & $57,600,000$ & $57,600,000$ & $57,600,000$ & $57,600,000$ \\
\hline 5 & $72,000,000$ & $72,000,000$ & $72,000,000$ & $72,000,000$ \\
\hline 6 & $86,400,000$ & $86,400,000$ & $86,400,000$ & $86,400,000$ \\
\hline 7 & $1.008 \mathrm{E}+8$ & $1.008 \mathrm{E}+8$ & $1.008 \mathrm{E}+8$ & $1.008 \mathrm{E}+8$ \\
\hline 8 & $1.152 \mathrm{E}+8$ & $1.152 \mathrm{E}+8$ & $1.152 \mathrm{E}+8$ & $1.152 \mathrm{E}+8$ \\
\hline 9 & $1.282 \mathrm{E}+8$ & $1.296 \mathrm{E}+8$ & $1.296 \mathrm{E}+8$ & $1.296 \mathrm{E}+8$ \\
\hline 10 & $1.294 \mathrm{E}+8$ & $1.420 \mathrm{E}+8$ & $1.421 \mathrm{E}+8$ & $1.422 \mathrm{E}+8$ \\
\hline
\end{tabular}

Table 3. Total CAPEX for the different cases considered.

\begin{tabular}{rcr}
\hline S/NO & CASES CONSIDERED & TOTAL CAPEX (\$MILLION) \\
\hline 1. & Natural Depletion without hydraulic fracture & 35.5 \\
2. & Depletion with Hydraulic Fracture at $\mathrm{Xf}=1000 \mathrm{ft}, \mathrm{Wf}=0.03 \mathrm{ft}$ and $\mathrm{Kf}=1000 \mathrm{md}$ & 38.4 \\
3. & Depletion with Hydraulic Fracture at $\mathrm{Xf}=2000 \mathrm{ft}, \mathrm{Wf}=0.06 \mathrm{ft}$ and $\mathrm{Kf}=2000 \mathrm{md}$ & 38.9 \\
4. & Depletion with Hydraulic Fracture at $\mathrm{Xf}=3000 \mathrm{ft}, \mathrm{Wf}=0.1 \mathrm{ft}$ and $\mathrm{Kf}=3000 \mathrm{md}$ & 39.4 \\
\hline
\end{tabular}

\subsection{Profit Indicators Utilized to Carry out Economic Calculations}

In the bid to have a clear understanding of the objective of this paper, the profit indicators considered are presented below: 


\subsubsection{Net Present Value}

Net present value commonly abbreviated as NPV is the commonly used method for considering the time value of money when making investment decisions [12]. It is a popular decision criterion. NPV and PV are used interchangeably. The "Net" is used to distinguish that the investment and/or operating costs have been deducted from net cash flow (NCF) [13] [14]. It helps to compare the value of a certain amount of money today to the value of the future amount of that same money and vice versa, taking into consideration inflation and returns. For instance, if one is given an investment opportunity, the NPV can be used as a tool for the evaluation of the profitability of a venture and also to make decisions with respect to capital budgeting [15]. NPV is thus calculated as follows:

$$
N=F\left[\frac{1}{(1+i)^{t}}\right]
$$

where:

$$
\begin{aligned}
& N=\text { Net present value, } F=\text { Future Value } \\
& {\left[\frac{1}{(1+i)^{t}}\right]=\text { Discount Factor }}
\end{aligned}
$$

Positive NPV shows that the investment opportunity is viable; therefore any investment opportunities with negative NPVs should be rejected [13].

\subsubsection{Payout Time}

Payout time commonly abbreviated as PO is an indicator of the rate at which cash flows are generated early in the project [13]. This address the concern, "The time it takes to get our investment recovered" It says nothing about the amount or rate of earnings after payout time. Payout time can also be called payback period. This determines the number of years that will have to elapse in order for the invested capital to be recovered out of the net incoming cashflow. It is the time at which cumulative NCR becomes zero. This method is mostly used by industry for assessing the economic desirability of an investment. The payback may or may not be with interest. The payout is calculated using the interpolation below:

$$
\begin{aligned}
& (\mathrm{PO}-\mathrm{IP}) /(\mathrm{FP}-\mathrm{IP}) \\
& =(0-\mathrm{CUM} \text { NCR at IP }) /(\mathrm{CUM} \text { NCR at FP }-\mathrm{CUM} \text { NCR at IP })
\end{aligned}
$$

where: $\mathrm{PO}=$ payout, $\mathrm{IP}=$ initial point, $\mathrm{FP}=$ final point, $\mathrm{CUM} \mathrm{NCR}=$ cumulative net cash recovery. In this equation, $\mathrm{PO}$ is made the subject of the equation.

When comparing the payback period for investment proposals, it is usually more desirable to have a short payback period than a longer one. This is because a short payback period indicates that the investment provides revenues early in its life, which is sufficient to cover the initial outlay [12].

\subsubsection{Discounted Cash Flow Rate of Return}

This is the discount interest rate such that NPV equals zero. It is among the widely used profit indicators in recent years. Discounted Cash Flow - Rate of 
Return is commonly abbreviated as DCF-ROR [13]. This is the interest rate which causes the equivalent receipts of a cash flow to equal the equivalent disbursements of the cash flow. It is also defined as the interest rate that reduces the worth of a series of receipt and disbursements to zero [12]. Calculating DCF-ROR involves an iterative (trial and error) process. This profit indicator is also known by some other names such as: Internal rate of return, Investors method, receipts versus disbursement method.

\subsubsection{Profit per Dollar Invested $(P / \$)$}

This is another important profit indicator used to evaluate the profitability of a project. It is a ratio of Cumulative NCR to CAPEX. Mathematically, it is calculated as [13] [14]:

$$
\mathrm{P} / \$=\frac{\text { Cumm.NCR }}{\text { CAPEX }}
$$

\section{Reservoir Overview}

The reservoir contains a lean gas condensate fluid with an API of $45.7^{\circ}$, a GOR of 56.9 MSCF/STB and a Condensate to Gas Ratio of 17.6 STB/MMSCF. The reservoir fluid was produced using a single vertical well model located at the centre of the square drainage area with an I.D of $0.5 \mathrm{ft}$ as the base case and a fractured single well model at various fracture halflength, fracture width and fracture permeability as the second case. The reservoir was initially above dewpoint with initial reservoir pressure of 4868 psia but declined below dewpoint pressure of 4191 psia due to production.

\section{Results and Discussions}

To analyse the profitability of hydraulic fracturing, economic analysis was performed to ascertain if the execution of the project will be economically viable. It is usually good to proceed with projects if the profitability calculations are in line with the following decision rules [14].

\subsection{Net Present Value (NPV)}

From Table 4 below, the NPV at an expected rate of return of $10 \%$ for the unfractured reservoir which is the sum of all the present values in that column is equal to $\$ 445.3$ Million. From Table 5, fracturing the reservoir at $\mathrm{Xf}=1000 \mathrm{ft}$, $\mathrm{Wf}=0.03 \mathrm{ft}$ and $\mathrm{Kf}=1000 \mathrm{md}$ generated an NPV of $\$ 455.5$ Million at $10 \%$ discount rate. This increase in NPV at this fracture parameter as seen in Figure 1 below is due to the increase in cumulative liquid recovery as seen in Table 1 above. This shows that the additional liquid recovered at the expiration of the production period was able to offset the additional cost of hydraulic fracturing. From Table 6, increasing the fracture parameters to Xf $=2000 \mathrm{ft}, \mathrm{Wf}=0.06 \mathrm{ft}$ and $\mathrm{Kf}=2000 \mathrm{md}$ gave an NPV of $\$ 455$ Million at $10 \%$ discount rate. Table 7 shows that further increase in fracture parameters to Xf $=3000 \mathrm{ft}, \mathrm{Wf}=0.1 \mathrm{ft}$ and $\mathrm{Kf}=3000 \mathrm{md}$ yielded an NPV of $\$ 453.5$ Million dollars at $10 \%$ discount rate 
after 10 years of production. The decrease in NPV at these fracture parameters as shown in Table 8 clearly indicates that the additional liquid recovered at the end of the production period was not enough to compensate for the additional cost of hydraulic fracturing.

\subsection{Pay out (P.0)}

Pay Out is the point where Cumulative NCR changes to positive. From Table 4 for natural depletion without hydraulic fracture, the P.O lies between $1^{\text {st }}$ and $2^{\text {nd }}$ year that is, P.O is 1.52 yrs. From Table 5, the P.O lies between $1^{\text {st }}$ and $2^{\text {nd }}$ year, fracturing the reservoir at $\mathrm{Xf}=1000 \mathrm{ft}, \mathrm{Wf}=0.03 \mathrm{ft}$ and $\mathrm{Kf}=1000 \mathrm{md}$ generated a P.O of 1.59 yrs. From Table 6, the P.O lies between $1^{\text {st }}$ and $2^{\text {nd }}$ year, increasing the fracture parameters at $\mathrm{Xf}=2000 \mathrm{ft}, \mathrm{Wf}=0.06 \mathrm{ft}$ and $\mathrm{Kf}=2000 \mathrm{md}$ gave a P.O of 1.6 yrs. From Table 7, the P.O lies between $1^{\text {st }}$ and $2^{\text {nd }}$ year, extending the fracture parameters at $\mathrm{Xf}=3000 \mathrm{ft}, \mathrm{Wf}=0.1 \mathrm{ft}$ and $\mathrm{Kf}=3000$ md gave a $\mathrm{P} . \mathrm{O}$ of 1.62 yrs. The increase in P.O as seen in Table 8 for the hydraulic fractured reservoir is due to the additional cost incurred by the hydraulic fracturing job which delayed the payout time.

\subsection{Profit per Dollar Invested}

From Table 4 the Cumulative Net Cash Recovery (CNCR) for Natural Depletion without fracture after 10 years is $\$ 865.7$ Million and the CAPEX is $\$ 35.5$ Million, the profit per dollar invested is $\$ 24.4$. From Table 5, fracturing the reservoir at $\mathrm{Xf}=1000 \mathrm{ft}, \mathrm{Wf}=0.03 \mathrm{ft}$ and $\mathrm{Kf}=1000 \mathrm{md}$ gave a profit per dollar invested of $\$ 23.2$ after 10 yrs of production. From 6, increasing the fracture parameters at Xf $=2000 \mathrm{ft}, \mathrm{Wf}=0.06 \mathrm{ft}$ and $\mathrm{Kf}=2000 \mathrm{md}$ yielded a profit per dollar invested of $\$ 22.9$ after 10 yrs of production. From Table 7, further increase of fracture parameters at $\mathrm{Xf}=3000 \mathrm{ft}$, $\mathrm{Wf}=0.1 \mathrm{ft}$ and $\mathrm{Kf}=3000 \mathrm{md}$ yielded a profit per dollar invested of $\$ 22.6$ after 10 yrs of production. The decrease in profit per dollar invested for the fractured cases as seen in Table 8 is due to the additional cost of hydraulic fracturing which could not be compensated by the additional liquid recovered.

\subsection{Discounted Cash Flow-Rate of Return (DCF-ROR)}

DCF-ROR was obtained from the plot of NPV against interest rate as shown in Figures 1-4. It is the interest rate that discounts NPV to zero. From Figure 1 and Table 8, DCF-ROR for Natural Depletion without fracture is $88 \%$. From Table 5 fracturing the reservoir at $\mathrm{Xf}=1000 \mathrm{ft}$, Wf $=0.03 \mathrm{ft}$ and $\mathrm{Kf}=1000 \mathrm{md}$ gave a DCF-ROR of $92 \%$ as shown in Figure 2 and Table 8 . This increase in DCF-ROR as seen in Table 8 and Figure 1 is due to the increased liquid recovery witnessed at the fracture parameter. Table 6 shows that increasing the fracture parameters to $\mathrm{Xf}=2000 \mathrm{ft}, \mathrm{Wf}=0.06 \mathrm{ft}$ and $\mathrm{Kf}=2000 \mathrm{md}$ gave a DCF-ROR of $87 \%$ as shown in Figure 3. From Table 7, further increase in parameters at Xf $=3000 \mathrm{ft}, \mathrm{Wf}=0.1 \mathrm{ft}$ and $\mathrm{Kf}=3000 \mathrm{md}$ yielded a DCF-ROR of $88 \%$ as seen in Figure 4 and Table 8 . The decrease in DCF-ROR at these fracture parameters 
A. Kerunwa et al.

clearly shows that the additional liquid recovered was not able to offset the additional cost of hydraulic fracturing.

Table 4. Cash Flows for Natural Depletion without Hydraulic Fracture.

\begin{tabular}{|c|c|c|c|c|c|c|c|c|c|c|c|c|}
\hline Time(Yrs) & 0 & 1 & 2 & 3 & 4 & 5 & 6 & 7 & 8 & 9 & 10 & NPV \\
\hline $\mathrm{Gp}(\mathrm{BSCF})$ & 0 & 14.4 & 28.8 & 43.2 & 57.6 & 72 & 86.4 & 100.8 & 115.2 & 128.2 & 129.4 & \\
\hline $\mathrm{Np}(\mathrm{MMSTB})$ & 0 & 0.253 & 0.49 & 0.67 & 0.80 & 0.89 & 0.940 & 0.957 & 0.958 & 0.96 & 0.958 & \\
\hline CAPEX $(\$ M M)$ & -35.5 & 0 & 0 & 0 & 0 & 0 & 0 & 0 & 0 & 0 & 0 & \\
\hline OPEX $(\$ M M)$ & 0 & 3.0 & 3.0 & 3.0 & 3.0 & 3.0 & 3.0 & 3.0 & 3.0 & 3.0 & 3.0 & \\
\hline Gross $\operatorname{Rev}(\$ M M)$ & 0 & 36.4 & 72 & 106 & 139 & 171 & 201 & 230 & 259 & 285 & 287 & \\
\hline NCR (\$MM) b/4 Royalty and Tax & -35.5 & 33.4 & 69 & 103 & 136 & 168 & 198 & 227 & 256 & 282 & 284 & \\
\hline Royalty + Tax (\$MM) $48.5 \%$ of NCR & 0 & 16 & 33.5 & 50 & 66 & 81.5 & 96 & 110.1 & 124.2 & 136.8 & 137.7 & \\
\hline NCR (\$MM) after Royalty and Tax & 0 & 17 & 35.5 & 53 & 70 & 86.5 & 102 & 116.9 & 131.8 & 145.2 & 146.3 & \\
\hline CUM. NCR (\$MM) & -35.5 & -18.3 & 17 & 70 & 140 & 226.5 & 328.5 & 445.4 & 577.2 & 722.4 & 865.7 & \\
\hline PV@10\% & -35.5 & 15.5 & 29.4 & 39.9 & 47.8 & 53.7 & 57.6 & 60 & 61.5 & 61.6 & 56.4 & 445.8 \\
\hline PV@ 30\% & -35.5 & 13.1 & 21 & 24.1 & 24.5 & 23.3 & 21.1 & 18.6 & 16.2 & 13.7 & 10.6 & 150.8 \\
\hline PV@ @5\% & -35.5 & 11.3 & 15.8 & 15.7 & 13.8 & 11.4 & 9 & 6.9 & 5.2 & 3.8 & 2.5 & 59.9 \\
\hline PV@ @8\% & -35.5 & 9.4 & 11 & 9.1 & 6.7 & 4.6 & 3 & 1.9 & 1.2 & 0.7 & 0.4 & 12.5 \\
\hline PV@ @ 100\% & -35.5 & 8.5 & 8.88 & 6.6 & 4 & 2.7 & 1.59 & 0.9 & 0.5 & 0.29 & 0.1 & -1.3 \\
\hline PV @ 150\% & -35.5 & 6.8 & 5.7 & 3.4 & 1.79 & 0.88 & 0.4 & 0.19 & 0.09 & 0.04 & 0.01 & -16.2 \\
\hline
\end{tabular}

Table 5. Cash Flows for Fractured Case (At Xf $=1000 \mathrm{ft}, \mathrm{Wf}=0.03 \mathrm{ft}, \mathrm{Kf}=1000 \mathrm{md}$ ).

\begin{tabular}{|c|c|c|c|c|c|c|c|c|c|c|c|c|}
\hline Time(Yrs) & 0 & 1 & 2 & 3 & 4 & 5 & 6 & 7 & 8 & 9 & 10 & NPV \\
\hline $\mathrm{Gp}(\mathrm{BSCF})$ & 0 & 14.4 & 28.8 & 43.2 & 57.6 & 72 & 86.4 & 100.8 & 115.2 & 129.6 & 142 & \\
\hline Np(MMSTB) & 0 & 0.23 & 0.49 & 0.684 & 0.834 & 0.941 & 1.01 & 1.046 & 1.056 & 1.056 & 1.056 & \\
\hline CAPEX $(\$ M M)$ & -38.4 & 0 & 0 & 0 & 0 & 0 & 0 & 0 & 0 & 0 & 0 & \\
\hline $\operatorname{OPEX}(\$ M M)$ & 0 & 3.0 & 3.0 & 3.0 & 3.0 & 3.0 & 3.0 & 3.0 & 3.0 & 3.0 & 3.0 & \\
\hline Gross $\operatorname{Rev}(\$ M M)$ & 0 & 36.4 & 72.3 & 106.9 & 140.2 & 172.2 & 203.1 & 233 & 262.1 & 290.9 & 315.7 & \\
\hline NCR(\$MM) b/4 Royalty and Tax & -38.4 & 33.4 & 69.3 & 103.9 & 137.2 & 169.2 & 200.1 & 230 & 259.1 & 287.9 & 312.7 & \\
\hline Royalty + Tax (\$MM) $48.5 \%$ of NCR & 0 & 16.2 & 33.6 & 50.4 & 66.5 & 82.1 & 97.05 & 111.6 & 125.7 & 139.6 & 151.7 & \\
\hline NCR (\$MM) after Royalty and Tax & 0 & 17.2 & 35.7 & 53.5 & 70.7 & 87.1 & 103.1 & 118.5 & 133.4 & 148.3 & 161 & \\
\hline CUM. NCR (\$MM) & -38.4 & -21.2 & 14.5 & 68 & 138.7 & 225.8 & 328.9 & 447.4 & 580.8 & 729.1 & 890.1 & \\
\hline PV@10\% & -38.4 & 15.6 & 29.5 & 40.2 & 48.3 & 54.1 & 58.2 & 60.8 & 62.2 & 62.9 & 62.1 & 455.5 \\
\hline PV@30\% & -38.4 & 13.2 & 21.1 & 24.4 & 24.7 & 23.5 & 21.4 & 18.9 & 16.4 & 14 & 11.7 & 150.8 \\
\hline PV@ 50\% & -38.4 & 11.5 & 15.9 & 15.9 & 14 & 11.5 & 9.05 & 6.9 & 5.2 & 3.9 & 2.8 & 58.1 \\
\hline PV@ @8\% & -38.4 & 9.6 & 11 & 9.2 & 6.7 & 4.6 & 3 & 1.9 & 1.2 & 0.7 & 0.5 & 10.1 \\
\hline PV@100\% & -38.4 & 8.6 & 8.9 & 6.7 & 4.4 & 2.7 & 1.6 & 0.9 & 0.5 & 0.3 & 0.2 & -3.54 \\
\hline PV@150\% & -38.4 & 6.9 & 5.7 & 3.4 & 1.8 & 0.9 & 0.4 & 0.2 & 0.09 & 0.04 & 0.02 & -18.9 \\
\hline
\end{tabular}


Table 6. Cash Flows for Fractured Case (At Xf $=2000 \mathrm{ft}, \mathrm{Wf}=0.06 \mathrm{ft}, \mathrm{Kf}=2000 \mathrm{md}$ ).

\begin{tabular}{|c|c|c|c|c|c|c|c|c|c|c|c|c|}
\hline Time(Yrs) & 0 & 1 & 2 & 3 & 4 & 5 & 6 & 7 & 8 & 9 & 10 & NPV \\
\hline $\mathrm{Gp}(\mathrm{BSCF})$ & 0 & 14.4 & 28.8 & 43.2 & 57.6 & 72 & 86.4 & 100.8 & 115.2 & 129.6 & 142.1 & \\
\hline Np(MMSTB) & 0 & 0.253 & 0.49 & 0.684 & 0.834 & 0.941 & 1.01 & 1.047 & 1.056 & 1.056 & 1.056 & \\
\hline CAPEX $(\$ M M)$ & -38.9 & & 0 & 0 & 0 & 0 & 0 & 0 & 0 & 0 & 0 & \\
\hline $\operatorname{OPEX}(\$ M M)$ & 0 & 3.0 & 3.0 & 3.0 & 3.0 & 3.0 & 3.0 & 3.0 & 3.0 & 3.0 & 3.0 & \\
\hline Gross Rev (\$MM) & 0 & 36.4 & 72.3 & 106.9 & 140.2 & 172.2 & 203.1 & 233 & 262.1 & 290.9 & 315.9 & \\
\hline NCR $(\$ M M) b / 4$ Royalty and Tax & -38.9 & 33.4 & 69.3 & 103.9 & 137.2 & 169.2 & 200.1 & 230 & 259.1 & 287.9 & 312.9 & \\
\hline Royalty + Tax (\$MM) $48.5 \%$ of NCR & 0 & 16.2 & 34 & 50.4 & 66.5 & 82.1 & 97.0 & 111.6 & 125.7 & 139.6 & 151.8 & \\
\hline NCR (\$MM) after Royalty and Tax & 0 & 17.2 & 35.7 & 53.5 & 70.7 & 87.1 & 103.1 & 118.5 & 133.4 & 148.3 & 161.1 & \\
\hline CUM. NCR (\$MM) & -38.9 & -21.7 & 14 & 67.5 & 138.2 & 225.3 & 328.4 & 446.9 & 580.3 & 728.6 & 889.7 & \\
\hline PV@10\% & -38.9 & 15.6 & 29.5 & 40.2 & 48.3 & 54.1 & 58.2 & 60.8 & 62.2 & 62.9 & 62.1 & 455 \\
\hline PV@30\% & -38.9 & 13.2 & 21.1 & 24.4 & 24.7 & 23.5 & 21.4 & 18.9 & 16.4 & 14 & 11.7 & 150.3 \\
\hline PV@ 50\% & -38.9 & 11.5 & 15.9 & 15.9 & 14 & 11.5 & 9.05 & 6.9 & 5.2 & 3.9 & 2.8 & 57.6 \\
\hline PV@ 80\% & -38.9 & 9.6 & 11 & 9.2 & 6.7 & 4.6 & 3 & 1.9 & 0.9 & 0.7 & 0.5 & 9.3 \\
\hline PV@ @100\% & -38.9 & 8.6 & 8.9 & 6.7 & 4.4 & 2.7 & 1.61 & 0.92 & 0.5 & 0.3 & 0.2 & -4.04 \\
\hline PV@150\% & -38.9 & 6.9 & 5.7 & 3.4 & 1.8 & 0.9 & 0.4 & 0.2 & 0.09 & 0.04 & 0.02 & -19.4 \\
\hline
\end{tabular}

Table 7. Cash Flows for Fractured Case (At Xf $=3000 \mathrm{ft}, \mathrm{Wf}=0.1 \mathrm{ft}, \mathrm{Kf}=3000 \mathrm{md}$ ).

\begin{tabular}{|c|c|c|c|c|c|c|c|c|c|c|c|c|}
\hline Time (Yrs) & 0 & 1 & 2 & 3 & 4 & 5 & 6 & 7 & 8 & 9 & 10 & NPV \\
\hline Gp(BSCF) & 0 & 14.4 & 28.8 & 43.2 & 57.6 & 72 & 86.4 & 100 & 115 & 129 & 142 & \\
\hline Np(MMSTB) & 0 & 0.253 & 0.491 & 0.684 & 0.834 & 0.941 & 1.011 & 1.048 & 1.057 & 1.057 & 1.057 & \\
\hline CAPEX $(\$ M M)$ & -39.4 & 0 & 0 & 0 & 0 & 0 & 0 & 0 & 0 & 0 & 0 & \\
\hline OPEX $(\$ M M)$ & 0 & 3.0 & 3.0 & 3.0 & 3.0 & 3.0 & 3.0 & 3.0 & 3.0 & 3.0 & 3.0 & \\
\hline Gross Rev (\$MM) & 0 & 36.4 & 72.3 & 107 & 140.2 & 172.2 & 203.1 & 233 & 262.1 & 291 & 316 & \\
\hline NCR $(\$ M M)$ b/4 Royalty and Tax & -39.4 & 33.4 & 69.3 & 104 & 137.2 & 169.2 & 200.1 & 230 & 259.1 & 288 & 313 & \\
\hline Royalty + Tax (\$MM) $48.5 \%$ of NCR & 0 & 16.2 & 33.6 & 50.4 & 66.5 & 82.1 & 97.0 & 111.6 & 125.7 & 139.7 & 151.8 & \\
\hline NCR (\$MM) after Royalty and Tax & 0 & 17.2 & 35.7 & 53.6 & 70.7 & 87.1 & 103.1 & 118.5 & 133.4 & 148.3 & 161.2 & \\
\hline CUM. NCR (\$MM) & -39.4 & -22.2 & 13.5 & 67.1 & 137.8 & 224.9 & 328 & 446.5 & 579.9 & 728.2 & 889.4 & \\
\hline PV@10\% & -39.4 & 15.6 & 29.5 & 40.2 & 48.3 & 54.1 & 58.2 & 60.8 & 62.2 & 62.9 & 62.2 & 453.5 \\
\hline PV@30\% & -39.4 & 13.2 & 21.1 & 24.4 & 24.7 & 23.5 & 21.4 & 18.9 & 16.4 & 14 & 11.7 & 149.8 \\
\hline PV@ @5\% & -39.4 & 11.5 & 15.9 & 15.9 & 14 & 11.5 & 9 & 6.9 & 5.2 & 3.9 & 2.8 & 57.1 \\
\hline PV@ @8\% & -39.4 & 9.6 & 11 & 9.2 & 6.7 & 4.6 & 3 & 1.9 & 1.2 & 0.7 & 0.5 & 9.1 \\
\hline PV@ @100\% & -39.4 & 8.6 & 8.9 & 6.7 & 4.4 & 2.7 & 1.61 & 0.92 & 0.5 & 0.3 & 0.2 & -4.5 \\
\hline PV@ @150\% & -39.4 & 6.9 & 5.7 & 3.4 & 1.8 & 0.9 & 0.4 & 0.2 & 0.09 & 0.04 & 0.02 & -19.9 \\
\hline
\end{tabular}

Table 8. Summary of the Economic Analysis Carried Out.

\begin{tabular}{crrrr}
\hline CASES CONSIDERED & $\begin{array}{r}\text { NPV @ 10\% } \\
\text { (MM\$) }\end{array}$ & $\begin{array}{r}\text { DCF-ROR } \\
\text { (\%) }\end{array}$ & $\begin{array}{r}\text { PAY-OUT PROFIT PER DOLLAR } \\
\text { (YEARS) }\end{array}$ & $\begin{array}{r}\text { INVESTED (MM\$) } \\
\text { Case 1: Natural Depletion Without Fracture }\end{array}$ \\
\hline Case 2: Fractured Case at $\mathrm{Xf}=1000 \mathrm{ft}, \mathrm{Wf}=0.03 \mathrm{ft}, \mathrm{Kf}=1000 \mathrm{md}$ & 455.8 & 88 & 1.52 & 24.4 \\
Case 3: Fractured Case at $\mathrm{Xf}=2000 \mathrm{ft}, \mathrm{Wf}=0.06 \mathrm{ft}, \mathrm{Kf}=2000 \mathrm{md}$ & 455 & 87 & 1.59 & 23.2 \\
Case 4: Fractured Case at $\mathrm{Xf}=3000 \mathrm{ft}, \mathrm{Wf}=0.1 \mathrm{ft}, \mathrm{Kf}=3000 \mathrm{md}$ & 453.5 & 88 & 1.62 & 22.9 \\
\hline
\end{tabular}




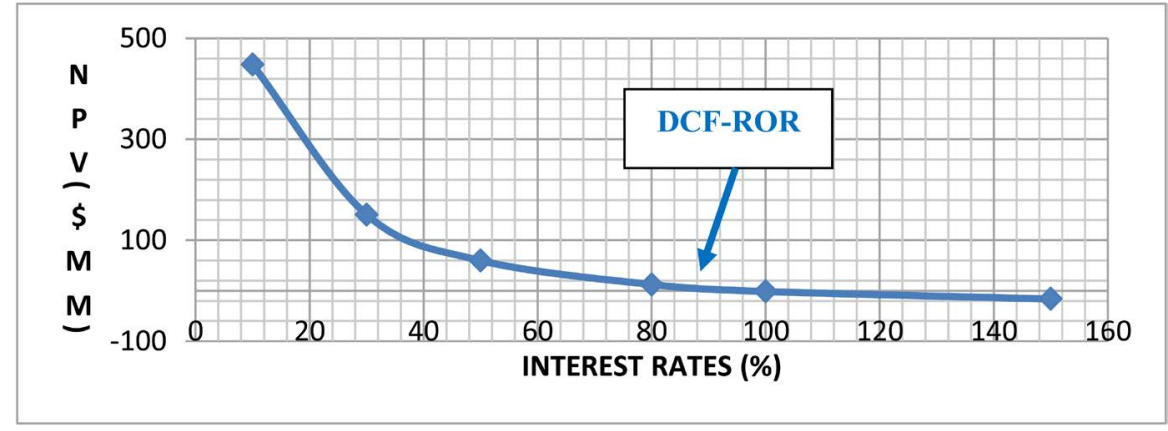

Figure 1. NPV against DCF-ROR for Natural Depletion without Hydraulic Fracture.

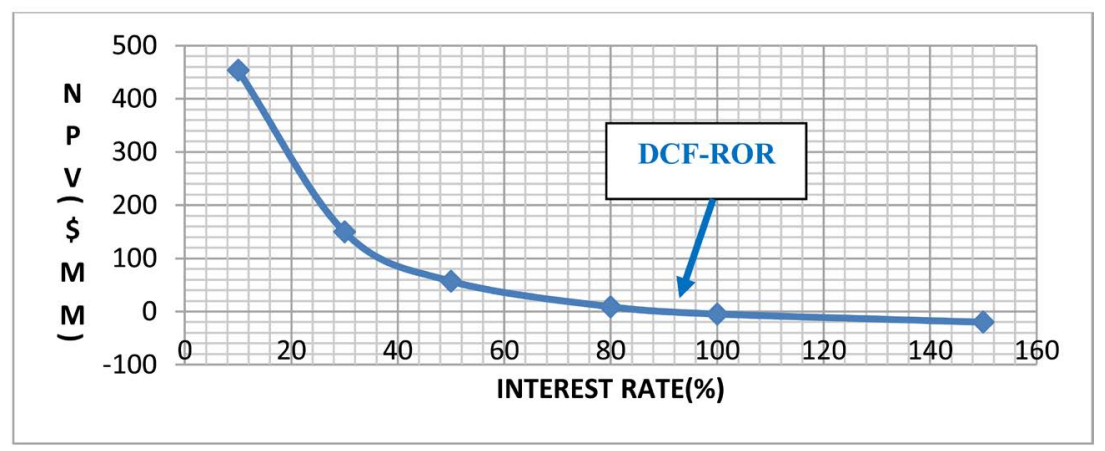

Figure 2. NPV against Interest Rates for Fractured Case at $\mathrm{Xf}=1000 \mathrm{ft}, \mathrm{Wf}=0.03 \mathrm{ft}, \mathrm{Kf}=$ $1000 \mathrm{md}$.

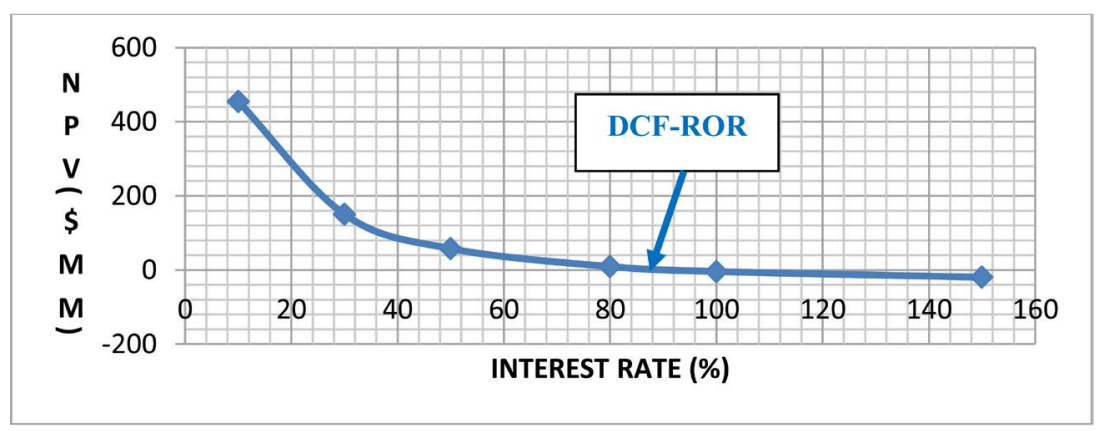

Figure 3. NPV against Interest Rates for Fractured Case at $\mathrm{Xf}=2000 \mathrm{ft}, \mathrm{Wf}=0.06 \mathrm{ft}, \mathrm{Kf}=$ $2000 \mathrm{md}$.

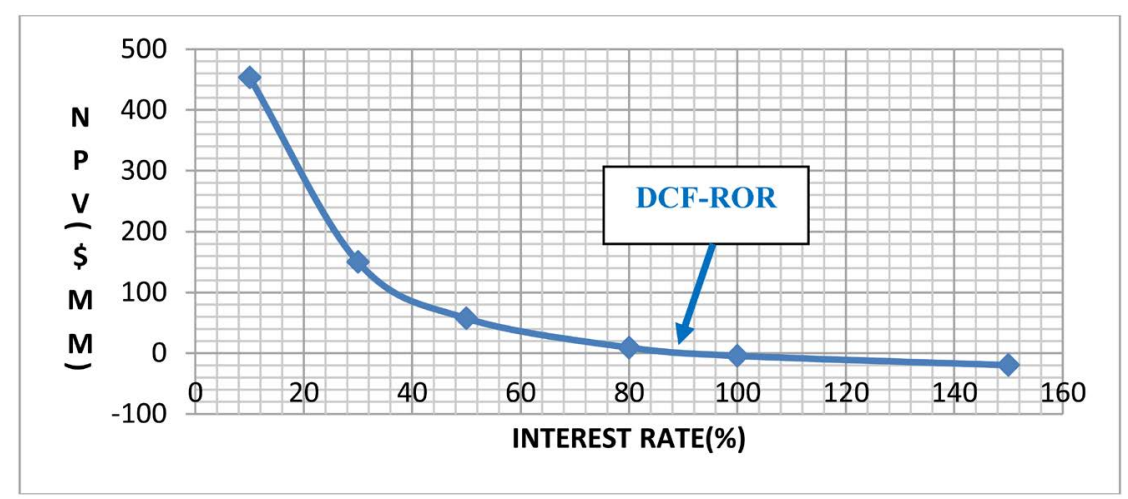

Figure 4. NPV against Interest Rates for Fractured Case at $\mathrm{Xf}=3000 \mathrm{ft}, \mathrm{Wf}=0.1 \mathrm{ft}, \mathrm{Kf}=$ $3000 \mathrm{md}$. 


\section{Conclusions}

The results of the economic analysis of hydraulic fracturing from a gas condensate reservoir operating below dewpoint show that:

1) The additional liquid recovered by continuous increase in fracture half-length, fracture width and fracture permeability may not be able to offset the additional cost incurred by hydraulic fracturing. This is because the reservoir contains a lean gas condensate fluid which is characterised with a low liquid yield. This is manifested by the profit per dollar invested calculated.

2) The NPV obtained by fracturing the reservoir at a fracture half-length of $1000 \mathrm{ft}$, fracture width of $0.03 \mathrm{ft}$ and fracture permeability of $1000 \mathrm{md}$ gave the highest amount when compared with the NPV obtained when the reservoir is unfractured and that obtained by fracturing the reservoir at other fracture parameters.

3) Fracturing the reservoir at $\mathrm{Xf}=1000 \mathrm{ft}, \mathrm{Wf}=0.03 \mathrm{ft}$ and $\mathrm{Kf}=1000 \mathrm{md}$ gave a higher DCF-ROR when compared with other cases considered. Fracturing the reservoir gave a later payout which resulted from the additional cost incurred due to fracturing.

4) Also fracturing the reservoir resulted to a $10.2 \%$ increase in the additional liquid recovered after the simulation period compared with the cumulative liquid recovered when the reservoir was unfractured.

\section{Acknowledgements}

The authors greatly appreciate the assistance of O'bmond Energy Nig. Ltd. for providing the data utilized in this study. Special thanks to Engr Chijioke Eze of O’bmond Energy Nig. Ltd. for his advice.

\section{Conflicts of Interest}

The authors declare no conflicts of interest regarding the publication of this paper.

\section{References}

[1] Cenk, T., Harun, K., Aditya, T., \& Karthik, B. (2016) An Investigation of Gas Recycling in Fractured Gas Condensate Reservoirs. Abu Dhabi International Petroleum Exhibition and Conference, Abu Dhabi, UAE, 7-10 November 2016, 1-32.

[2] Richard, N.-H. (2013) Elements of Hydraulic Fracturing. Oilfield Review, 25, 51-52.

[3] Shepherd, M. (2009) Factors Influencing Recovery from Oil and Gas Field. In: Oil Field Production Geology, AAPG Memoir 91, Chapter 5, GeoScienceWorld, McLean, VA, 37-46. https://doi.org/10.1306/13161187M913372

[4] Guo, B., Lyons, W.C. and Ghalambor, A. (2007) Petroleum Production Engineering, a Computer-Assisted Approach. Gulf Professional Publishing, Burlington, MA.

[5] Zeeshan, T., Al-Hashim, H.S., Ahmed, S. and Aneeq, N.J. (2016) A Novel Methodology to Optimize the Parameters of Hydraulic Fracturing in Gas Condensate Reservoirs. The International Petroleum Technology Conference, Bangkok, Thailand, 14-16 November 2016. 
[6] Li, F., Billy, W.H., Jamaluddin, A., Jairam, K., Robert, M., Gary, A.P., Alexander, S. and Curtis, H.W. (2005) Understanding Gas Condensate Reservoirs. Oilfield Review, 17, 14-27.

[7] Andrey, F., Xinli, J., Timothy, M. and Vitaly, K. (2016) Fast Economic Analysis and Optimization of Fracture-Stimulated Wells in Condensate Reservoirs. The SPE/IAEE Hydrocarbon Economics and Evaluation Symposium, 17-18 May 2016, Houston, TX.

[8] Ignatyev, A.E., Mukminov, I. and Vikulova, E.A. (2011) Multistage Hydraulic Fracturing in Horizontal Wells as a Method for the Effective Development of Gas/condensate Fields in the Arctic Region. The SPE Arctic and Extreme Environments Conference and Exhibition, Moscow, 18-20 October 2011.

https://doi.org/10.2118/149925-RU

[9] Sheraz, A, Atta M.K., Ijaz, A. and Osama, H.K. (2016) Enhancing Recoveries from a Low Permeable Gas-Condensate Reservoir through Hydraulic-Fracturing \& EOR Technologies. The PAPG/SPE Pakistan Section Annual Technical Conference and Exhibition, Islamabad, Pakistan, 21-23 November 2016.

[10] Ravari, R.R., Wattenbarger, R.A. and Ibrahim, M. (2005) Gas Condensate Damage in Hydraulically Fractured Wells. The Asia Pacific Oil and Gas Conference and EXhibition, Jarkata, Indonesia, 5-7 April 2005. https://doi.org/10.2118/93248-MS

[11] Mogan, J., Pope, G.A. and Sharma, M.M. (2006) Effect of Non-Darcy Flow on Well Productivity of a Hydraulically Fractured Gas/Condensate Well. The SPE Annual Technical Conference and Exhibition, San Antonio, TX, 24-27 September 2006. https://doi.org/10.2118/103025-MS

[12] Ezeh, J.C. and Ezeh, G.N. (2000) Fundamentals of Engineering Economy. M.C. Computer Press Publishing, Nnewi, Nigeria.

[13] Ikoku, C.U. (1985) Economic Analysis and Investment Decisions. Wiley Publishing, Hoboken, NJ.

[14] Main, M.A. (2011) Project Economics and Decision Analysis. 2nd Edition, PennWel Corporation.

[15] Abekah, B. (2016) Development of a Gas Condensate Reservoir: Case Study of the Niger Delta. Master's Thesis, African University of Science and Technology, Abuja, Nigeria. 


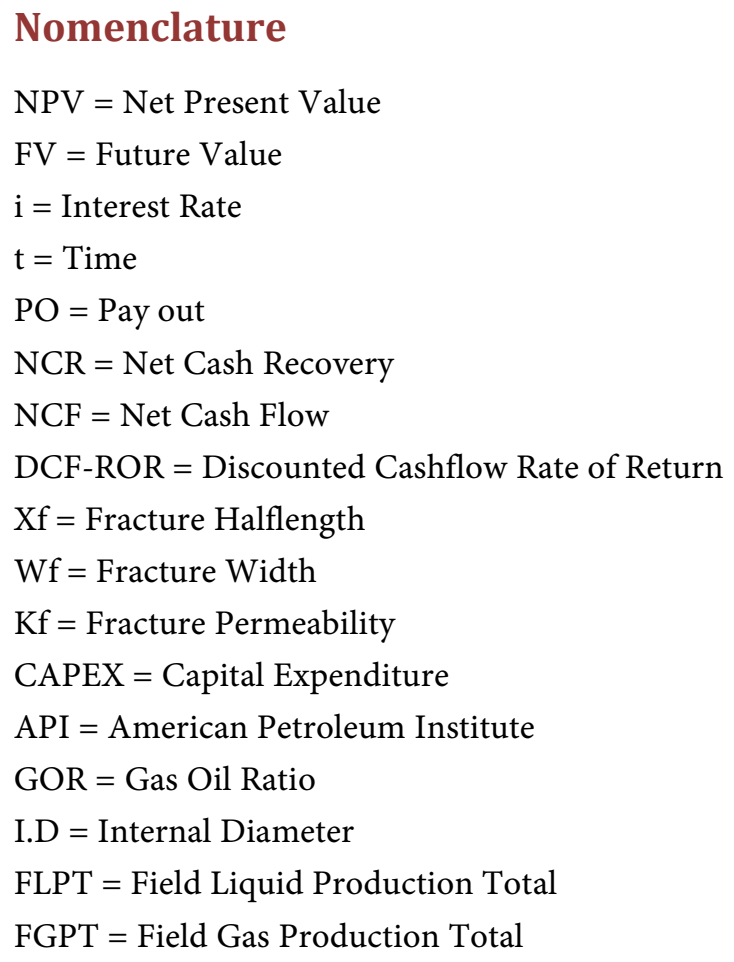

